\title{
Da segurança à cobiça: um breve relato da transição dos argumentos abolicionistas nas propostas legislativas no Parlamento
}

\author{
From security to greed: a brief account of the transition from \\ abolitionist arguments to legislative proposals in Parliament
}

Guilherme Del Negro*

Resumo: Os vívidos debates legislativos no parlamento brasileiro sobre a proibição do tráfico e a abolição da escravidão desmontam a imagem de uma apatia institucionalizada ou de um comprometimento dissimulado com a causa abolicionista no cenário internacional - existiam preocupações sinceras com os rumos da nação. No artigo, sistematizo os argumentos mais comumente invocados no parlamento imperial e periodizo os projetos de lei ali apresentados, de modo a associar ideias e leis. Dessa associação, concluo que, ao passo que a ideia da abolição amadurecia e ganhava corpo, os argumentos transitaram da defesa da segurança nacional para a condenação da cobiça.

Palavras-chave: Debates legislativos, Abolição da escravidão, Tráfico negreiro.

Abstract: The vivid parliamentary debates in Brazil regarding the prohibition of slave trade and the abolition of slavery challenge the idea that the parliament was apathetic or faked its commitment only to impress the international arena - there were sincere concerns regarding the future of the nation. In this article, I systematize both the ideas that thrived in parliament and the drafts regarding slavery and slave trade, in order to entangle laws and concepts. With this in mind, I conclude that, whilst the idea of abolition was ripening, the speeches changed their focus from security concerns to the condemnation of greed.

Keywords: Parliamentary debates, Abolition of slavery, Slave trade.

* Doutorando em Direito - Universidade de Brasília, Brasília/DF, Brasil. Mestre em Direito - Bolsista CAPES. Professor Assistente no Instituto Rio Branco. E-mail: guilhermedelnegro@gmail.com

(c) EY Direito autoral e licença de uso: Este artigo está licenciado sob uma Licença Creative Commons. Com essa licença você pode compartilhar, adaptar, para qualquer fim, desde que atribua a autoria da obra, forneça um link para a licença, e indicar se foram feitas alterações. 


\section{Introdução}

Em tese publicada em 1896, W. E. B. Du Bois notou que a abolição da escravidão, nos Estados Unidos da América, traduziu-se em três diferentes esforços: a luta por proibir juridicamente a escravidão, a luta por elevar os padrões morais da nação e a luta por tornar a escravidão não rentável ${ }^{1}$. Com esses três critérios, o autor quer afirmar a política, a economia e a moral simultaneamente como instrumentos e como argumentos para a luta abolicionista.

No Brasil, a utilização de instrumentos econômicos e morais teve menor importância, visto que as iniciativas abolicionistas foram tomadas, em maior parte, pela via política direta e pela pressão social sobre os órgãos legiferantes, diferentemente da experiência norte-americana, na qual a participação civil organizada envolveu, inclusive, amplo boicote a produtos fabricados com mão-de-obra escrava em comunidades protestantes e campanhas religiosas para a excomunhão de proprietários de escravos. Por outro lado, o uso de argumentos políticos, econômicos e morais foi abundante. Em diversas iniciativas legislativas brasileiras, os argumentos dos abolicionistas articulam essa tríade de razões para justificar políticas específicas para a extinção, gradual ou imediata, do tráfico ou da escravidão.

No artigo, examino as principais iniciativas legislativas discutidas no Parlamento do Império do Brasil e na Assembleia Nacional Constituinte (ANC) de 1823-24 com a finalidade de sistematizar e analisar os argumentos contidos nas propostas mais relevantes, desde a representação de José Bonifácio até a Lei Áurea. Para tanto, adoto a tipologia tripartite de W. E. B. Du Bois, sistematizando tais argumentos em: políticos, econômicos e morais.

Pretendo mostrar que as questões políticas, morais e econômicas ainda estavam sujeitas a significativas controvérsias à época, e não a uma simples hipocrisia institucionalizada. Havia dúvidas quanto à melhor solução para o problema da escravidão - oscilava-se entre a extinção do tráfico, a abolição gradual e a abolição imediata.

Compreender as discussões subjacentes aos esforços abolicionistas no Brasil auxilia-nos a afastar lugares comuns que consideram a abolição da escravidão um processo natural. Tanto o determinismo fundado em causas econômicas, caracterizado por Sidney Chaloub como aquele em que "a decadência e a extinção da escravidão se explicam em última análise a partir da lógica da produção e do mercado", quanto o suposto "despertar" diante de direitos humanos aparentemente preexistentes, não refletem a pluralidade de concepções que coexistiram de 1823 a 1889.

O artigo está estruturado em três partes. Primeiramente, sistematizo as propostas legislativas tramitadas no parlamento, para periodizá-las em relação às soluções propostas: a proibição do tráfico, a abolição gradual e a abolição imediata. Em segundo momento, examino os argumentos levantados para a abolição, segundo a tipologia já explicitada: de início, os argumentos 
políticos, em seguida, os econômicos, e, por fim, os morais. Por último, associo a periodização dos projetos de lei com os argumentos então existentes, construindo uma história do pensamento legislativo que descreve a mudança das propostas abolicionistas ao longo do tempo.

É certo que a crença na superioridade civilizacional europeia permeia as discussões de nosso Parlamento, no que é possível afirmar que o pensamento da elite nacional estava colonizado: sabiam que não eram europeus, mas sempre almejavam sê-lo. ${ }^{3}$ Ater-se a isso, contudo, é uma leitura extremamente simplista, e, como se poderá ver, não estávamos completamente alienados: a atenção à situação nacional permeou várias propostas para acelerar ou atrasar o ímpeto abolicionista. As discussões parlamentares brasileiras, que culminaram na aprovação da Lei Áurea, não se devem somente a pressões estrangeiras, mas são o resultado de forças internas legitimamente nacionais. É o que veremos.

\section{A sucessão de propostas legislativas: do tráfico à abolição imediata}

As propostas abolicionistas oscilaram, ao longo do tempo, quanto aos mecanismos propostos para se chegar ao fim da escravidão. Foram três as formas articuladas para tanto, que podem ser agrupadas em distintos períodos: de início, deu-se prioridade à extinção do tráfico, posteriormente à abolição gradual e, por fim, à abolição imediata.

Em um primeiro momento, as propostas legislativas se limitavam a abordar a abolição do tráfico negreiro, não a abolição da escravidão. Essa característica está de acordo com o cenário externo. Na Inglaterra, foi fundada em 1780 a Sociedade para a Abolição do Tráfico Escravo, mas a primeira sociedade a lutar pela abolição da escravidão (embora gradual), foi instituída somente em 1823, coincidentemente o mesmo ano em que José Bonifácio apresentaria sua Representação sobre a Escravidão na ANC. Além disso, as pressões da Inglaterra sobre o Brasil na época da independência concentravamse exclusivamente sobre o problema do tráfico, abolido naquela nação em 1807 (o Slave Trade $A c t)^{4}$. A escravidão, por sinal, só viria a ser abolida na Inglaterra por lei de 1833 (o Slavery Abolition Act).

Há duas razões principais para a ênfase inicial se restringir ao tráfico: por um lado, acreditava-se à época que "a supressão do tráfico acarretaria o fim da escravidão" . Essa crença se deve principalmente à noção de que a elevada mortandade do negro seria algo natural e incontornável, e que o recurso ao tráfico seria a única forma de manter a escravidão. Por outro lado, prevalecia à época a noção iluminista de que a ordem social deveria ser preservada - as transições sociais deveriam ser graduais, sendo mudanças bruscas um mal social $^{6}$. Nas palavras de José Bonifácio: "torno a dizer porém que eu não desejo ver abolida de repente a escravidão; tal acontecimento traria consigo grandes males". ${ }^{7}$ A proibição do tráfico levaria gradualmente ao fim da escravidão, da melhor maneira possível: sem violar o direito de propriedade. 
No Brasil, foram muitos os projetos de lei visando à supressão do tráfico. A proposta de José Bonifácio dispunha em seu artigo $1^{\circ}$ sobre a cessação do tráfico de escravos africanos dentro de 4 a 5 anos. Pouco depois, em 19.5.1826, o deputado Clemente Pereira apresentou projeto de lei que proibia a entrada de escravos em nossos portos ao fim do ano de 1840 .

Algumas medidas legais foram efetivamente aprovadas e, na década de 30, parecia que poríamos um ponto final ao tráfico. Em 23.11.1826, o Brasil e a Inglaterra firmaram Convênio que, ao lado de estender os tratados anglo-portugueses ao Brasil, também dispunha sobre a extinção do tráfico africano, num prazo de três anos após a troca de ratificações. ${ }^{8} \mathrm{Em} 7.11 .1831$, foi sancionada lei pelo Regente Feijó que visava a dar efeito ao fim do tráfico, na qual declarava livres todos os escravos entrados no Brasil desde o estrangeiro, à exceção daqueles que trabalhassem em embarcações de países que admitiam a escravidão.

A Lei Feijó de 1831, contudo, "não pegou", de modo que sua vigência não pôs fim, na prática, ao tráfico de escravos, nem enfraqueceu significativamente a escravidão como instituição social ${ }^{9}$. Diz Joaquim Nabuco em $O$ Abolicionismo que:

Com efeito, a grande maioria desses homens, sobretudo no Sul, ou são africanos, importados depois de 1831, ou descendentes destes. Ora, em 1831, a lei de 7 de novembro declarou no seu artigo $1^{\circ}$ : "Todos os escravos que entrarem no território ou nos portos do Brasil vindos de fora ficam livres". Como se sabe, essa lei nunca foi posta em execução, porque o governo brasileiro não podia lutar com os traficantes; mas nem por isso deixa ela de ser a carta de liberdade de todos os importados depois da sua data. ${ }^{10}$

O senador João Antonio Rodrigues de Carvalho também percebeu as dificuldades de aplicação dos instrumentos de 1826 e de 1831 e diagnosticou a situação: autoridades locais coadjuvavam com o tráfico, várias contravenções ainda eram justificadas pela ideia de que a lavoura não se sustentaria sem escravos, a fiscalização do extenso litoral era impraticável, o interesse dos vendedores ainda vicejava e grande parte da população não se convencia da justeza da medida ${ }^{11}$. Nesse contexto, propôs engenhoso procedimento em projeto de 25.4.1834, a dispor que: (i) o registro de todos os escravos era obrigatório ao nascimento ${ }^{12}$, (ii) a compra e venda de escravos só ocorreria com a transferência do registro e (iii) eram alforriados os escravos sem registro. Como o tráfico de recém-nascidos e de crianças pequenas para o Brasil era bastante difícil, dadas as condições da viagem transatlântica, a maioria dos escravos já chegava aos nossos portos em idades que seriam incompatíveis com registro originário lícito. Tal proposta, infelizmente, não avançou. 
Em 30.6.1837, o senador Felisberto Caldeira Brant Pontes propôs projeto de lei que proibia a importação de escravos, basicamente reiterando a Lei Feijó. A tramitação desse projeto foi longa, graças a tecnicismos sobre a legalidade do julgamento iniciado pelo juiz (ex officio) do crime de “importação de escravos ou de pretos livres, ou de tentativa". É esse o projeto que, com algumas emendas, seria convertido na Lei Eusébio de Queiroz, de 5.9.1850, que proíbe o tráfico e o assemelha ao crime de pirataria. Essa lei deu resultados, reduzindo o número de escravos a entrarem no Brasil.

Os dados quinquenais sobre o desembarque de escravos no Brasil, compilados pelo IBGE, corroboram as narrativas usuais sobre a Lei Feijó e sobre a Lei Eusébio de Queiroz ${ }^{13}$. No quinquênio 1831-35, os desembarques de escravos reduziram-se consideravelmente em relação ao anterior, passando de 250.200 a 93.700 escravos. Contudo, em 1836-40 já houve nova escalada, para 240.600 escravos, mantida em 1841-45. A redução só se consolidaria de $1846-50$ a $1851-55$, da ordem de 257.500 escravos para 6.100 escravos, assim prosseguindo até a abolição total.

Ao contrário das previsões iniciais, a supressão do tráfico não significou o fim da escravidão, no Brasil ou na Inglaterra. Isso afetou os traficantes de escravos, mas não levou os senhores de terras à falência. A persistência da viabilidade da escravidão, mesmo após a supressão do tráfico transatlântico ${ }^{14}$, impulsionou o movimento abolicionista para a abolição direta da escravidão.

Um problema fundamental ficava patente: para se pôr fim à escravidão, seria necessário mais do que acabar com o tráfico. Era necessário atacar diretamente essa instituição. Uma pergunta fundamental se pôs nesse contexto e se manteve sempre presente: sendo necessárias medidas para proscrever a escravidão, elas deveriam contemplar a abolição imediata ou gradual?

O ideal iluminista da manutenção da ordem formava a opinião dominante entre os defensores da abolição gradual. A fábula de Montesquieu sobre os escravos de Volsinien era uma constante: libertados de imediato, sem que tivessem absorvido o apreço às instituições liberais, os forros escravizariam seus mestres ${ }^{15}$. $\mathrm{O}$ argumento econômico da desestruturação agrícola também justificava a substituição gradativa do escravo pelo trabalhador livre. Por fim, havia o argumento humanista da abolição gradual, conformado no discurso de José Bonifácio, o Moço, em 17.7.1867: ninguém deseja "que as cartas de alforria passadas pelo governo do meu país se assemelhem a passaportes de miséria" 16 .

As propostas de abolição gradual estrearam no parlamento nacional na década de 1830, com a suposta vigência do convênio Brasil-Inglaterra. Contudo, como nota Joaquim Nabuco, a intensificação do debate só se deu na década de 1850: antes dela, apenas uma iniciativa esboçou a abolição gradual além de José Bonifácio: a dos deputados França ${ }^{17}$. 
O deputado Antônio Ferreira França, em 18.5.1830, apresentou projeto propondo o fim da escravidão em 50 anos, com a alforria fracionada anualmente. Junto a seu filho, Ernesto Ferreira França, reapresentou o projeto em 16.6.1831, incluindo a alforria imediata dos "escravos da nação" (aqueles que exerciam função pública para a Coroa). A ideia de que os serviços públicos deveriam dar o exemplo, libertando, desde já, seus escravos, foi comum e consta também no projeto do senador João Vieira de Carvalho, de 22.9.1835. A proibição da escravidão em conventos, proposta pelo senador Silveira da Motta, em 26.1.1864, também segue essa lógica.

Uma das vias possíveis era a abolição dos nascidos de ventre escravo. Em 1850, o deputado Silva Guimarães apresentou projeto que foi sumariamente rejeitado pela Presidência da Câmara ${ }^{18}$. Em 1852, incluiu mitigação em novo projeto, permitindo que os senhores pudessem demandar o trabalho dos jovens até os 14 anos, para compensar os gastos com a criação. Um dos cinco projetos apresentados pelo senador Pimenta Bueno em 23.1.1866 dispunha sobre a liberdade dos filhos de escravos, com várias especificidades. Em 1870, é a vez do deputado Perdigão Malheiro (o filho) novamente propor a liberdade dos nascidos.

Também se pensou na abolição gradual pela criação de caixas públicas, que custeariam a alforria de escravos com impostos e multas públicas. Tal mecanismo já fora proposto por José Bonifácio em sua Representação sobre a Escravidão, com a Caixa de Piedade. O senador Pimenta Bueno, em 1866, com os Fundos de Redenção. Em 1869, o deputado Manuel Francisco Corrêa pensou no produto de loterias. Em 1870, o deputado José de Alencar propôs verbas anuais às sociedades particulares de emancipação.

Além da abolição gradual, propostas legislativas se multiplicaram entre as décadas de 1850 e $1870^{19}$ no sentido de melhorar o trato dos cativos. Tanto apologéticos da escravidão quanto partidários da abolição gradual defenderam a humanização da escravidão. Exemplificam essas iniciativas: o projeto do deputado João Maurício Wanderley, de 1854, a dispor que os senhores continuavam obrigados a alimentar os escravos alforriados que não pudessem se sustentar; o projeto do senador Francisco Montezuma de 1865, a prever a redução das penas para o crime de insurreição; um dos projetos do senador Pimenta Bueno de 23.1.1866, a oficializar a folga no sétimo dia, a proibir a venda separada de casais e a garantir a defesa judicial dos escravos. Em 23.5.1870, o deputado Perdigão Malheiro (o filho) propôs a abolição da pena de açoites e a revogação da rígida lei de 10.6.1835.

Os anos de 1866-67 representaram o annus mirabilis para as propostas de abolição gradual. A partir desse momento, a abolição gradual passa a contar com o apoio do Imperador, e discute-se uma política de longo prazo para a abolição. 
Joaquim Nabuco indica que os cinco projetos de lei do senador Pimenta Bueno, cuja finalidade era estender ao Brasil instrumentos já adotados em Portugal para a abolição gradual, foram patrocinados pelo Imperador. ${ }^{20}$ Além disso, D. Pedro encarregou o Conselho de Estado do estudo da questão da emancipação em $1867,{ }^{21}$ cabendo-lhe formar estatísticas para um exame beminformado. Por último, na Fala do Trono de 22.5.1867, Dom Pedro II afirma que:

O elemento servil não pode deixar de merecer oportunamente a vossa consideração, provendo-se de modo que, respeitada a propriedade atual, e sem abalo profundo em nossa primeira indústria - a agricultura - sejam atendidos os altos interesses que se ligam à emancipação. ${ }^{22}$

Em 20.8.1867, os projetos do senador Pimenta Bueno foram consolidados em proposta do senador Nabuco de Araújo, com algumas supressões. Em 1869, a Câmara dos Deputados encarrega Comissão Especial da preparação de parecer e de projeto para a emancipação dos escravos. As medidas aí propostas combinam vários dos elementos já citados, (i) melhorando as condições de trabalho, (ii) assegurando a liberdade das gerações futuras e (iii) minimizando os prejuízos dos proprietários - imediata emancipação dos escravos da nação, proibição de escravos nos conventos, criação de fundo de emancipação, melhora no trato dos escravos, proteção dos libertos e libertação dos recém-nascidos, os quais deveriam indenizar seus senhores diretamente ou trabalhar até os 21 anos.

Em 12.5.1871, o Ministro da Agricultura, Theodoro Machado da Silva, embasando-se em vários dos trabalhos da Comissão Especial, apresenta o projeto que, em 28.9.1871, viria a se converter na Lei Rio Branco, a libertar os nascidos de ventre escravo. O mecanismo era o seguinte: na vigência da lei, as crianças já nasceriam libertas, mas os senhores deveriam criar os filhos de suas escravas até os oito anos e, após essa idade, poderiam reaver seus gastos por duas vias: (i) utilizando os serviços dos menores até os 21 anos ou (ii) recebendo título de dívida pública no valor de 600 mil réis. Os senhores que maltratassem esses jovens durante o período de servidão perderiam de imediato o direito à compensação e os libertos seriam entregues a associações autorizadas pelo governo. Decretos do mesmo ano regulamentaram a expedição de cartas de liberdade e o registro público de escravos e libertos.

Em 15.7.1884, o senador Rodolfo Dantas, filho de Sousa Dantas e Presidente do Conselho de Ministros, apresentou o projeto de lei que viria a se converter na Lei Saraiva-Cotegipe. Nessa lei, além da libertação aos 60 anos de idade, também se previu a alforria nas hipóteses de: mudança de domicílio do escravo ${ }^{23}$, omissão de rematrícula no ano seguinte e penhor sem cláusula constituti. Também se instituiu um fundo de emancipação, com valores até 900 mil réis. A lei foi regulamentada em 14.11.1885. 
Houve outras propostas de abolição gradual até o ano de 1887, às vésperas da deliberação sobre a Lei Áurea, cuja aprovação se deu dez dias após a abertura da sessão legislativa do ano de 1888. A abolição imediata, por sua vez, somente contou com um projeto, cujo resultado todos sabemos: trata-se da proposta apresentada pelo deputado Rodrigo da Silva em 8.5.1888, que viria a ser aprovada e convertida na Lei Áurea.

A Lei Áurea, aprovada no Brasil em 13.5.1888, é certamente a mais ríspida de todas as leis abolicionistas, em qualquer lugar do mundo. ${ }^{24} \mathrm{Com}$ somente dois artigos, diz singelamente: "É declarada extinta desde a data desta lei a escravidão no Brasil" e "Revogam-se as disposições em contrário". Teve vigência imediata, não implementou qualquer mecanismo transitório, nem dispôs sobre indenizações devidas aos senhores de escravos. É lei de abolição imediata e incondicionada, cuja viabilidade, até poucos anos antes, era completamente impensável.

\section{$O$ argumento político}

A Representação sobre a Escravidão, apresentada por José Bonifácio à ANC de 1823, enquadra o problema da escravidão no contexto da construção da nova ordem política nacional. A independência do Brasil e a proposta da Constituição exigiam que o projeto escravocrata fosse contrastado com as novas exigências da época.

$\mathrm{Na}$ opinião de José Bonifácio, a nova nação, pensada e arquitetada sobre princípios liberais, não se coadunaria com a escravidão, um resquício colonial que evitaria a caminhada rumo ao interesse nacional e uma ameaça que espreitaria a paz e a estabilidade da jovem nação 25 : “como poderá haver uma Constituição liberal e duradoura em um país continuamente habitado por uma multidão imensa de escravos brutais e inimigos?". ${ }^{26}$ A escravidão é um risco à estabilidade nacional e aos valores liberais.

A referência à brutalidade e à inimizade dos escravos, em José Bonifácio, não equivale ao racismo científico ${ }^{27}$ : o negro é um homem como os demais, não um bruto animal. Sua ira provém do sofrimento ao qual é submetido, nas fazendas ou nos porões dos navios.

$\mathrm{O}$ receio quanto à estabilidade nacional, explicitado pela pergunta de José Bonifácio, era justificável do ponto de vista da elite política. Dados coletados por Emilia Viotti da $\operatorname{Costa}^{28}$ indicam um enorme peso populacional dos escravos. O medo de um levante generalizado persistiu na literatura abolicionista. O imperativo de segurança nacional está presente, por exemplo, em referências de Perdigão Malheiro:

A escravidão é um dos maiores males que ora pesa sobre Vós [minha dileta pátria]. Cumpre examinar de perto as questões que ela sugere, e atacá-la com prudência, mas francamente 
e com energia, para que cessem as ilusões, e não durmam os Brasileiros o sono da indiferença, e da confiança infantil, sobre o vulcão e o abismo, criados pelo elemento servil da nossa sociedade. [...]

Entre nós, levantamentos, insurreições de escravos se tem dado, pode-se dizer, desde que, para desgraça de nossa pátria, a escravidão foi nela introduzida. (...) Os escravos, descendentes da raça Africana, que ainda conservamos, hão por vezes tentado, e ainda tentam, já por deliberação própria, já por instigações de estranhos, quer em crises de conflitos internacionais, quer intestinas; é o vulcão que ameaça constantemente a sociedade, é a mina pronta a fazer explosão à menor centelha... ${ }^{29}$

Como afirmou Perdigão Malheiros, levantes eram realidade constante em nosso país desde a adoção do trabalho escravo negro no século XVI. A preocupação das autoridades traduziu-se em contínua repressão criminal desses levantes. É representativa desses receios a justificativa dada pelo Ministro da Justiça, Aureliano Coutinho, em projeto de lei apresentado em 10.6.1833, que viria a se converter em lei em dois anos, para justificar o acirramento das punições dos escravos insurgentes:

Se a legislação até agora era fraca, e ineficaz para coibir tão grande mal, a que ora existe mais importante é, e menos garantidora da vida de tantos proprietários fazendeiros, que vivendo mui distantes uns dos outros não poderão contar com a existência, se a punição de tais atentados não for rápida e exemplar, nos mesmos lugares em que eles tiverem sido cometidos. A vossa penetração e sabedoria [dos senhores deputados e senadores] escusa quaisquer reflexões mais a tal respeito. ${ }^{30}$

À época da promulgação da Lei Áurea, ainda vigia o Código Criminal de 1830, que imputava graves penas aos escravos envolvidos em insurreições, inclusive a pena de morte, assim como a lei de 10.6.1835, que considerava que o julgamento pelo crime de insurreição não poderia ser objeto de recurso. A segurança pública justificou o acirramento da repressão contra os cativos, com uma miríade de projetos de lei durante as décadas de 1820 e 1830.

O discurso da segurança pública também justificou a tomada de medidas contra o tráfico. Com a proibição, esperava-se que a redução do influxo de negros aliviaria as pressões sociais. Eusébio de Queiroz, em 1850, alerta para "perigos gravíssimos" e "sintomas de natureza gravíssima" após levante em Campos, no Espírito Santo. ${ }^{31}$ 
As propostas de José Bonifácio, ao contrário de outras externadas em anos próximos, não tenderam para a resposta criminalizadora ou policialesca. A melhor solução para garantir a coesão social não seria o aumento da repressão, que incitaria maior inimizade social, mas simplesmente a abolição, evitando um choque entre escravos e senhores. José Bonifácio propõe que, para a estabilidade da Constituição liberal e duradoura, é necessária maior homogeneidade civil e física:

É tempo, pois, e mais que tempo, que acabemos com um tráfico tão bárbaro e carniceiro; é tempo também que vamos acabando gradualmente até os últimos vestígios da escravidão entre nós, para que venhamos a formar em poucas gerações uma Nação homogênea, sem o que nunca seremos verdadeiramente livres, respeitáveis e felizes. É da maior necessidade ir acabando tanta heterogeneidade física e civil; cuidemos pois em combinar desde já, em combinar sabiamente tantos elementos discordes e contrários, e em amalgamar tantos metais diversos, para que saia um todo homogêneo e compacto, que não se esfarele ao pequeno toque de qualquer nova convulsão política. ${ }^{32}$

A proposta de amalgamação social de José Bonifácio é muito avançada para a época, incluindo a previsão de se dar uma sesmaria de terra a "todos os homens de cor forros, que não tiverem ofício ou modo certo de vida" (artigo 10). ${ }^{33}$ Contudo, deve ser interpretada cum grano salis. Embora rejeitasse o racismo científico, José Bonifácio não admitia a integração sem ressalvas nem distinções. Fica claro que o autor trabalha com a óptica dos "graus de civilização". Melhor seria que a homogeneidade física existisse desde pronto; contudo, sendo isso impossível, deve-se dar a amalgamação por etapas. A Caixa de Piedade, entidade pública destinada a custear as manumissões, deveria dar preferência ao forro dos mulatos, depois dos crioulos, e, por fim, dos "escravos da Costa" (artigo 25). ${ }^{34} \mathrm{~A}$ integração dos negros aos brancos, após a abolição, seria paulatina, indo desde o mulato até o africano nato.

Ainda na década de 1870, há várias referências aos riscos à segurança pública. Em 1870, consta em parecer que "a tranquilidade e segurança" 35 deve ser garantida mediante uma transição gradual do elemento servil para o trabalho livre. Em 1871, outra comissão especial, para justificar a abolição gradual, faz referência a "graves perigos de bandos e acervos de escravos anualmente entregues em estado livre, e sem preparo, à sociedade". ${ }^{36}$

Por sua vez, Joaquim Nabuco segue a premissa mais ampla de José Bonifácio no sentido de que a pátria dependeria da abolição. A escravidão "excita o ódio entre as classes" e "produz uma aparência ilusória de ordem", que "há de forçosamente dar em resultado o desmembramento e a ruína do 
país". ${ }^{37}$ Com a escravidão, "nenhuma sociedade nacional existe senão no grau de molusco, isto é, sem vértebras nem individualização". ${ }^{38}$

Além disso, José Bonifácio explica que os caracteres culturais favorecidos pela escravidão não se compatibilizavam com o ideal das leis liberais a serem adotadas. A escravidão faz com que os senhores se tornem indolentes e traz consigo as demais vicissitudes da alma. ${ }^{39}$ Para que não houvesse descompasso entre as leis liberais e os maus costumes da colônia, o que, em última análise, levaria à impossibilidade do fiel cumprimento do regulamento, dever-se-ia dar o primeiro passo pela abolição do tráfico pela lei, o que levaria à paulatina modificação dos costumes. ${ }^{40}$

Os argumentos referentes à instabilidade política e à segurança nacional persistiram nos debates parlamentares até a década de 1870. Daí em diante, param de contar com qualquer relevância. A partir da década de 1880, são irrisórias as referências a um risco de rebelião generalizada após a abolição. Nos debates da Lei Saraiva-Cotegipe, o argumento não é posto em questão; nos da Lei Áurea, só o Senador João Maurício Wanderley alerta que no Peru os libertos "tornaram-se salteadores (...) e praticavam toda casta de barbaridade". ${ }^{41}$

Por fim, José Bonifácio também considerava que a abolição da escravidão era um imperativo em razão da monarquia constitucional que se viria a consolidar com a Constituição Imperial de 1824. Com fundamento na teoria das formas de governo de Montesquieu, a escravidão somente seria tolerável em governos despóticos, em que a servidão civil é um elemento comum, do qual a escravidão pouco se desvia. Na democracia e na monarquia, a escravidão afetaria o equilíbrio de poder e abalaria seus respectivos princípios fundadores: na primeira, a igualdade; na segunda, o espírito humano. ${ }^{42}$

Para Montesquieu, o elemento mais próprio da monarquia, sua causa moral de existência, é a honra ${ }^{43}$ - e essa não se coaduna de nenhuma forma com a escravidão. A estrutura constitucional que se agregava à monarquia brasileira após a independência aperfeiçoava esse sistema político nos moldes propostos por aquele filósofo, (i) evitando que o governo monárquico se tornasse um despotismo e (ii) inserindo certo grau de igualdade entre os súditos pela incorporação de valores liberais. A manutenção da escravidão, nesse contexto, impediria que os costumes nacionais formassem um ambiente propício para a nova realidade política: não seria possível cultivar o ambiente de fidalguia necessário para a monarquia com a ameaça de revolta sempre latente.

Nos debates legislativos posteriores, a preocupação com o projeto nacional não possui contornos tão claros como na proposta de José Bonifácio cujo momento histórico de enunciação, em plena $\mathrm{ANC}$, favoreceu a inserção da abolição como elemento político necessário para o nascimento da nova nação (causa sine qua non). As demais propostas já pressupõem a nação, sugerindo modificações para os seus destinos. $\mathrm{O}$ argumento político é securitizado, mas o temor de levantes perde importância quando a abolição gradual dá 
frutos. Desde então, as referências à abolição, muito mais do que um projeto político, abordam a tentativa de se elevar o padrão moral da pátria ou de se dar efetividade a determinado projeto econômico.

\section{O argumento econômico}

O debate abolicionista no parlamento também era riquíssimo do ponto de vista dos argumentos econômicos. Esse é o ponto mais longo na Representação sobre a Escravidão de José Bonifácio: a saída de divisas nacionais, a improdutividade da lavoura escravista e a indolência econômica dos senhores.

Ainda no século XVIII, Benjamin Franklin, em 1755, divulgou estudo no qual contrastava os custos e a produtividade do trabalho escravo nos EUA com aqueles do trabalhador livre na Inglaterra, concluindo que o escravo seria menos produtivo e mais caro. ${ }^{44}$ Tal obra teve grande repercussão entre os movimentos abolicionistas, dando roupagem científica aos argumentos da ineficiência do trabalho escravo e da suposta "preguiça" dos escravos. Vários abolicionistas chegaram a extrapolar inadequadamente as conclusões de Franklin, como Du Pont de Nemours, para afirmar que a escravidão não era lucrativa. ${ }^{45}$

A ideia da não lucratividade da escravidão e da ineficiência dos escravos foi ecoada por José Bonifácio, em 1823, como o primeiro ponto da defesa da abolição da escravatura e da proibição do tráfico de escravos: seria um dispêndio que não expandiria a produção nacional e que nunca poderia ser recuperado do exterior. Veja-se:

Com efeito, imensos cabedais saem atualmente deste Império para a África; e imensos cabedais se amortizam dentro deste vasto País, pela compra de escravos, que morrem, adoecem, e se inutilizam, e demais pouco trabalham. Que luxo inútil de escravatura também não apresentam nas Vilas e Cidades (...). E todavia [os escravos] custaram imensos cabedais, que se perderam para sempre, e que nem sequer pagam o juro do dinheiro empregado. ${ }^{46}$

Contudo, tal concepção não foi, de forma alguma, pacífica. Diversas manifestações nas décadas de 1830 a 1850 apontam para a grande lucratividade do trabalho escravo. Em projeto de 25.4.1834, o senador João Antônio Rodrigues de Carvalho afirmou que "grande parte de nossos concidadãos está persuadido (...) da necessidade que cada um se antolha de adquirir tais braços". ${ }^{47}$ Em voto de 1.6.1850, o senador Hollanda Cavalcanti reconheceu que a venda de escravos era realizada a preços tão baixos que os grandes interesses nesse comércio inviabilizavam medidas para a proibição do tráfico. ${ }^{48}$

A ideia de que a escravidão não seria lucrativa, com o passar do tempo, passou a ser abandonada diante do crescente realismo dos parlamentares. Os 
senhores insistiam em continuar comprando escravos e, mesmo após o fim do tráfico, ainda existia mercado paralelo de escravos - o argumento de que a escravidão levava a prejuízos parecia contradizer a realidade. Ao invés desse ponto, reforçam-se no Brasil discussões sobre o melhor rumo econômico da nação, no que argumentos dos fisiocratas e dos classicistas foram utilizados para fundamentar a abolição, como revisão da organização econômica.

Assim se sistematizam esses argumentos. Em primeiro lugar, lições de fisiocratas, como David Hume: a escravidão freia o crescimento populacional e não garante a sustentabilidade econômica. ${ }^{49} \mathrm{~A}$ mortalidade dos escravos é elevadíssima e o manejo precário da terra com o trabalho escravo empobrece e destrói os solos. A escravidão limitaria o horizonte produtivo e inviabilizaria o desenvolvimento. Em segundo lugar, o argumento da indolência que a escravidão gerava nos senhores seguia a óptica de autores classicistas: os maus hábitos da escravidão cegam os senhores quanto aos melhores interesses econômicos, não diversificando nem qualificando seus investimentos. ${ }^{50}$ Segundo Adam Smith, tampouco escravos e servos teriam interesse em melhorar a produção, por não desfrutarem do produto do trabalho. ${ }^{51}$ Essa ideia encontra respaldo na representação de José Bonifácio e no parecer no projeto da Lei Rio Branco. Neste, consta, de maneira muito interessante, que o trabalho escravo cria uma "aristocracia dos livres" que repudia o trabalho e somente valoriza a "sobranceria estulta, a preguiça improdutiva, a ociosidade viciosa". "O trabalho livre é empreendedor" e, com a abolição, "nobilitado ficará todo o trabalho". "Acaso se não prestará [a terra] a outros cultivos, quando a inteligência lhe proferir o seu Fiat?". ${ }^{2}$

$\mathrm{Na}$ linha de José Bonifácio, ${ }^{53}$ várias foram as manifestações posteriores a favor da abolição para o desenvolvimento de nossa agricultura, seja pelo melhor aproveitamento da renda da terra, seja pela adoção das melhores técnicas ou seja pela mudança de postura de nossos produtores. Tratou-se de argumento que chegou a fazer parte do discurso da Princesa Isabel na abertura da sessão parlamentar de 1888 , ao afirmar que são necessárias providências que "aviventem a indústria nacional". ${ }^{54}$

Tanto as críticas fisiocratas quanto as classicistas se concentravam não em criticar a suposta não lucratividade do trabalho escravo, mas em defender que o melhor projeto econômico da nação envolvia o cultivo da terra por mãos livres, não escravas.

Era inquestionável que o trabalho escravo era o sustentáculo da economia brasileira durante o século XIX. Até a década de 1850, a importância do elemento escravo traduziu-se na noção de que a economia dependia da escravidão, o que sugeria a inviabilidade econômica do projeto abolicionista. O parecer da Comissão Especial do Senado sobre projeto do senador Baptista de Oliveira, em 1.6.1850 55 e a exposição de motivos do senador João Antonio Rodrigues de Carvalho, em projeto de lei de $25.4 .1834,{ }^{56}$ sustentam que a maior 
parte do povo brasileiro não vê possível prescindir-se do trabalho escravo, para o bem da nação.

José Bonifácio, já em sua representação, tentava refutar essa teoria, com base no argumento comparado de que a escravidão não seria a única via para o desenvolvimento agrícola, como comprovado pela adoção do trabalho livre em outras regiões, e até em próprio solo brasileiro, de maneira mais sustentável:

Diz, porém, a cobiça cega, que os escravos são preciosos no Brasil, porque a gente dele é frouxa e preguiçosa. Mente, por certo. A Província de S. Paulo, antes da criação dos engenhos de açúcar, tinha poucos escravos, e todavia crescia anualmente em povoação e agricultura, e sustentavam de milho, feijão, farinha, arroz, toucinhos, carnes de porco, etc., a muitas outras províncias marítimas e interiores.

$\mathrm{Na}$ Conchinchina não há escravos, e todavia a produção e exportação do açúcar já montava em 1750 (...) e seu preço era baratíssimo no mercado; ora advirta-se, que todo este açúcar vinha de um pequeno país sem haver necessidade de estragar matas e esterilizar terrenos em rápida progressão, e se forem introduzindo os melhoramentos da cultura na Europa, de certos poucos braços, a favor dos arados e outros instrumentos rústicos, a agricultura ganhará pés diariamente, as fazendas serão estáveis, e o terreno, quanto mais trabalhado, mais fértil ficará. ${ }^{57}$

As ideias de José Bonifácio só encontram penetração a partir da década de 1860, quando surgem dúvidas sobre a rentabilidade da escravidão, mas restritas ao longo prazo.

No curto prazo, reconhecia-se, com grande dose de realismo, a relevância do latifúndio para a economia nacional, e considerava-se sua substituição findaria por desestabilizar a economia nacional - assim, a transição deveria ser gradual. Nesse sentido, o parecer da Comissão Especial da Câmara dos Deputados, em 24.5.1870, reforça a ideia do elemento servil como sustentáculo "da principal fonte de riqueza, a agricultura" ${ }^{58} \mathrm{e}$ defende a necessidade de se fazer uma transição gradual para minimizar as desvantagens inevitáveis no curto prazo.

Quanto ao longo prazo, a manifestação do senador Pimenta Bueno, ao apresentar seus cinco projetos, em 23.1.1866, exemplifica a proposta de que a abolição traria prejuízos econômicos imediatos, os quais deveriam ser minimizados por um adequado planejamento, mas levaria a benesses econômicas de longo prazo: 
O abalo será grande. Por mais bem inspiradas, e executadas que sejam as medidas, haverá desordens a lamentar; a produção agrícola, nossa única riqueza, estremecerá [...]. Na verdade, se a transformação for bem prevista e bem dirigida, passado algum tempo, cessará o desânimo, ressuscitará a coragem, e após desta a regeneração, o trabalho mais inteligente, o melhoramento dos processos agrícolas, os hábitos da economia, a honra do trabalho, o aperfeiçoamento dos costumes, a energia política. Será uma justa compensação providencial. ${ }^{59}$

O argumento inverso, do receio de desestruturação econômica no longo prazo, persistiu até as vésperas da aprovação da Lei Rio Branco, de 28.9.1871, atrasando a implementação de medidas que almejassem a abolição gradual: nunca se chegava a um consenso quanto ao prazo necessário para uma transição adequada. Nesse sentido, a manifestação do deputado Rodrigo da Silva contra o Projeto da Comissão Especial da Câmara dos Deputados alerta para os grandes gastos que a abolição traria e para o risco de redução da produção, que encolheria a receita pública:

Aconselha a prudência que não tomemos hoje um compromisso de tal ordem sem termos a convicção de que em outro dia estaremos em circunstâncias de poder satisfazêlo. [...] Ao passo que a emancipação caminhar irão faltando braços à lavoura. Daí a necessidade de ativar a introdução de ativar a introdução no país de braços trabalhadores. Como consequência direta à organização do trabalho livre, maior desenvolvimento da colonização e maior facilidade de meios de transporte. Aumento considerável na despesa pública. A deslocação do instrumento de trabalho dos centros agrícolas depreciará o valor da grande propriedade territorial, e produzirá um notável decrescimento na produção. Baixa na receita pública. Atenda-se para tudo isso e reconheça-se que os cálculos financeiros da exposição de motivos estão muito longe da verdade..$^{60}$

No parecer da comissão especial designada para avaliar o projeto de lei que viria a se converter na Lei Rio Branco, a ideia original de José Bonifácio é resgatada. Considera-se que "a frutífera liberdade dos braços e dos ânimos" traria “o adiantamento rural”, ao contrário daqueles locais em que há "a lavoura de nossas terras de mais escravaria", arruinadas "pelos enormes cabedais que aquele elemento de trabalho imobiliza" e pelo "péssimo trabalho servil". ${ }^{61}$ Além disso, afirma-se que "a própria agricultura pode bradar: é teu o interesse, tua res agitur". ${ }^{62}$ 
Na década de 1880, a controvérsia também passou a abranger o curto prazo. A ideia de que a abolição deveria ser feita em etapas, para que se minimizassem os males econômicos, passa a disputar com o argumento de que a abolição traria imediatas vantagens econômicas.

Esse novo argumento foi avançado com referência à experiência comparada da abolição, que já alcançava cerca de 40 anos em partes do globo, e à suposta inexistência de impactos econômicos (i) após a proibição do tráfico e (ii) desde a vigência da Lei Rio Branco. Contra tais argumentos, sustentavam alguns parlamentares a especificidade da experiência brasileira, na qual o peso da escravidão impossibilitava a comparação e na qual a agricultura servil era a principal fonte de renda.

Ambas as posições estão claramente apresentadas no parecer de Ruy Barbosa, em 4.8.1884, no projeto que viria a se converter na Lei SaraivaCotegipe. Com base em dados econômicos, ele afirmou que o passo à frente dado pelas Leis Eusébio de Queiroz e Rio Branco demonstrava deveríamos cair na armadilha da indispensabilidade da agricultura servil, pois os resultados econômicos da nova medida seriam positivos:

Já então corria em voga, a nosso respeito, o lema que nos reduz à condição de um estado puramente agrícola. Não obstante, houve espíritos assaz lúcidos, para anteverem, e clamarem, que a produção do país, não só não diminuirá, como, pelo contrário, havia de crescer (...).

Se se atentar para o que se passou nos anos que decorreram desde a extinção do tráfico, até que começou o contrabando de africanos, ver-se-á que, não só a agricultura não definhou, como, o que é extraordinário, todos os agricultores, que até então se achavam empenhados na praça de quem já tinham recebido adiantamentos de um e dois anos sobre as safras futuras, não só pagaram suas dívidas, como se foram tornando grandes proprietários.

A lição da experiência não mentiu. A produção agrícola do país, que, no exercício financeiro de 1849 a 1850, época da terminação definitiva do tráfico, era de 55.000:000\$; no ano subsequente excedeu de 67.000:000\$, crescendo progressivamente sempre, de modo que dez anos depois daquela data subia a 112.000:000\$. [...] Onde está, entretanto, a desorganização social com que nos apavoravam? A paralisação do trabalho agrícola? A insurreição geral? A destruição da lavoura? A bancarrota financeira? (...) a renda (...) cresceu, em doze anos, $29 \% .{ }^{63}$ 
O senador Dantas, em discurso de 30.7.1886, também afirmou que "quanto mais depressa acabarmos com ela [a escravidão], mais depressa nascerá para este Império americano uma época de prosperidade". ${ }^{64}$

Ainda na década de 1880, alguns deputados continuavam a insistir na especificidade da experiência nacional para afastar comparações, retomando ideias constantes no parecer da comissão designada pela Câmara dos Deputados para estudar o projeto de lei que viria a se converter na Lei Rio Branco, assim manifestadas:

Se as outras nações a aboliram (e sempre com debates prévios e precauções minuciosas), pouco mais fizeram do que prestar culto a um grande princípio, ao passo que no Brasil é-se impelido pelo mesmo pensamento moral, mas levado a efeito com infinitamente maior sacrifício. ${ }^{65}$

Se os argumentos econômicos tinham dominado as discussões sobre a abolição gradual, nas breves discussões da Lei Áurea são quase inexistentes os embates sobre as repercussões no curto e no longo prazo, à exceção da voz isolada do senador João Maurício Wanderley, que preludia "uma perturbação quase geral na lavoura de São Paulo", ${ }^{66}$

\section{$O$ argumento moral}

O trajeto das discussões morais sobre a escravidão é, muito provavelmente, o mais complexo de todos os três abordados neste artigo, quando considerado do ponto de vista mundial. Desde o Século XV, a Igreja Católica dera os primeiros passos: com a Bula do Papa Pio II em 7.10.1462, a escravidão entre os cristãos é considerada um magno crime segundo a lei divina. No século XVIII, fora a vez da filosofia, com Bodin e Hutcheson a celebrarem a liberdade como um direito inato. ${ }^{67}$

No contexto das discussões parlamentares brasileiras, tudo parecia ser mais simples. A admissão de que a escravidão seria uma violação perante as leis natural e divina foi quase inconteste. ${ }^{68} \mathrm{~A}$ escravidão era imoral, mas persistiram dúvidas no que respeitava à liberdade imediata dos cativos e ao direito de propriedade dos senhores.

As críticas à imoralidade da escravidão já aparecem em nossos debates legislativos desde a independência. José Bonifácio, na citada Representação sobre a Escravidão, de 1823, considerou que a escravidão era uma violação dos deveres cristãos e da lei natural:

Como se a escravidão perpétua não fosse um crime contra o direito natural, e contra as leis do Evangelho, como disse. As leis civis, que consentem estes crimes, são não só culpadas de todas as misérias, que sofre esta porção de 
nossa espécie, e de todas as mortes e delitos que cometem os escravos, mas igualmente o são de todos os horrores, que em poucos anos deve produzir uma multidão imensa de homens desesperados, que já vão sentindo o peso insuportável da injustiça, que os condena à uma vileza e miséria sem fim. ${ }^{69}$

Nas décadas de 1830 a 1850, a escravidão também foi condenada em várias exposições de motivos, a exemplo daquela do deputado João Antônio Rodrigues de Carvalho, em projeto de 25.4.1834, que considerou o tráfico "detestado pelo unânime sentir das Nações civilizadas". ${ }^{70}$ Até o conservador Hollanda Cavalcanti afirmou que: "posto que sejamos uma nação nova, devemos concorrer pela nossa parte (da minha pelo menos hei de concorrer) com o maior contingente que pudermos para o bem da humanidade". ${ }^{11}$

As fortes oposições até a década de 1850 às iniciativas abolicionistas não se fundaram na existência de uma norma moral a permitir a escravidão. Quando não eram silentes quanto à questão moral da escravidão, os parlamentares culpavam as pressões inglesas, enquanto violação de nossa soberania, ou criticavam a precipitação das medidas propostas. Exemplos desses argumentos podem ser retirados do voto do senador Paula Souza, de 2.7.1850:

Bem convencido dos males que em um país produz a escravidão, e, por conseguinte, a importação africana que a perpetua, entendi sempre, entretanto, que a convenção que a proibiu sem ter preparado os ânimos, e sem dispor meio algum de substituição, foi irrefletida, e que seria, portanto, ilusória. [...] O governo inglês, porém, certo de sua força, esquecido de que sem os meios morais nada de eficaz se conseguirá, redobrou os meios violentos, promulgando a sua lei de agosto de 1845 [o Bill Aberdeen], e por ela usurpando a independência e soberania do Brasil. (...) Será, pois, nestas circunstâncias, que deveremos fazer leis para mais eficaz repressão (...), sem darmos primeiros passos para sair deste estado? ${ }^{72}$

Sobre isso, Argemiro Eloy Gurgel afirma que:

(...) a questão da extinção do tráfico atlântico foi um tema constante na pauta do legislativo, até a sua efetiva abolição, na década de 1850. Sempre que havia oportunidade, alguns deputados, da linha mais conservadora, protestavam contra o acordo lesivo à pátria firmado pelo governo brasileiro com os ingleses. Em suas exposições de motivos, ressaltavam preliminarmente que não estavam em oposição à nova filosofia do século no que dizia respeito à valorização 
dos princípios humanitários e ao direito natural, pois reconheciam que esse tipo de comércio não poderia continuar indefinidamente, porém entendiam como precipitada a atitude do Poder Executivo de se comprometer em torná-lo ilegal num prazo tão curto. ${ }^{73}$

A inexistência de grandes oposições até então não significa que o enquadramento da escravidão como uma violação da lei natural penetrou rapidamente no discurso oficial brasileiro. Em 22.10.1845, menos de cinco anos antes da promulgação da Lei Eusébio de Queiroz, o governo brasileiro apresentou reclamação ao governo inglês contra a aplicação da Bill Aberdeen, por considerar que a autorização dada aos navios ingleses para capturar navios brasileiros suspeitos de traficar escravos e para encaminhar seus tripulantes a julgamento em tribunais do almirantado e do vice-almirantado violava o direito das nações. Nesse documento, Paulino José Soares de Souza, o Visconde do Uruguai, então Ministro das Relações Exteriores do Brasil, além de invocar a soberania brasileira e de silenciar quanto ao direito natural, também afirma que o tráfico de escravos naquela época não violava o direito das gentes, pois várias nações ainda o praticavam e não desejavam proibi-lo. É o protesto:

Nem é concebível como possa o tráfico ser considerado hoje pirataria, segundo o direito das gentes, quando ainda no ano de 1807 afirmava Lord Eldon no parlamento britânico - que o tráfico tinha sido sancionado por parlamentos em que tinham assento os jurisconsultos mais sábios, os teólogos mais esclarecidos, e os homens de estado mais eminentes; quando Lord Hawksbury, depois conde de Liverpool, propunha que as palavras - inconsistentes com os princípios de justiça e humanidade - fossem riscadas do preâmbulo da lei que abolia o tráfico de escravos; quando enfim o conde de Westmoreland declarava - que ainda que ele visse os presbiteros e prelados, os metodistas e os pregadores do campo, os jacobinos e os assassinos reunidos em favor da medida da abolição do tráfico de escravos, ele havia de levantar bem alto a sua voz contra ela no parlamento.

Não é concebível como possa o tráfico ser considerado hoje pirataria, segundo o direito das gentes, quando não há muitos anos ainda a mesma Inglaterra não se reputava infamada em negociar em escravos africanos [...].

Escravos índios conserva presentemente a Grã-Bretanha. Rússia, França, Espanha, Portugal, Estados Unidos da América do Norte, Brasil, e outras potências ainda não aboliram a escravidão. 
Óbvio é, portanto, que fatos que tantas nações praticam atualmente, e que ainda não há muitos anos eram praticados por todo o mundo, não serão com justiça considerados pirataria senão entre povos que como se os classificarem expressamente nos seus tratados. ${ }^{74}$

É importante notar que, no parlamento brasileiro, ao contrário das discussões norte-americanas ainda durante a década de 1850, não foram levantados argumentos ultrarracistas quanto à adequação da escravidão à lei natural, como os de James Holcombe, congressista dos Confederados, que, em 1858, publicou o influente artigo intitulado Is Slavery Consistent with Natural Law?. Com base na razão humana, ${ }^{75}$ na prevalência do bem geral ${ }^{76}$ e nas liberdades pessoais e políticas, James Holcombe afirmava que a raça inferior só poderia alcançar a perfeição natural com o constante suporte da raça superior. A igualdade jurídica seria prejudicial, pois ela tenderia a extinguir a raça inferior. ${ }^{77} \mathrm{~A}$ escravidão seria o mais justo dos ajustes, pois faria com que "as paixões egoístas da raça superior provejam conforto à raça inferior". ${ }^{78}$ Citando o pensador vitoriano Thomas Carlyle, ${ }^{79}$ James Holcombe afirma:

\begin{abstract}
"De todos os direitos do homem", diz Carlyle, "o direito do homem ignorante de ser guiado pelo mais sábio, de ser por ele gentil e firmemente mantido no caminho certo, é o mais indispensável. É o primeiro a ser ordenado pela natureza. A luta pelo aperfeiçoamento da sociedade passa por alcançá-lo e por conformar-se a ele. Se a liberdade tem algum significado, é o de desfrutar desse direito, pelo qual todos os outros direitos podem ser desfrutados. É um direito e um dever divino para ambos os agentes e a soma de todas as obrigações sociais entre eles." 80
\end{abstract}

Desde 1867, a condenação moral da escravidão passou também a integrar o discurso oficial brasileiro, com o reconhecimento pelo Imperador, na Fala do Trono, dos "altos interesses" na solução do problema da escravidão. Trata-se, desde então, de uma realidade a ser combatida tanto do ponto de vista dos debates legislativos quanto do ponto de vista do discurso oficial, mantendo-se assim até a abolição definitiva.

Ainda que a escravidão fosse quase unanimemente considerada uma violação da lei natural e do direito das gentes, as conclusões daí deduzidas poderiam divergir, como continuou a ocorrer mesmo após a promulgação da Lei Eusébio de Queiroz. Alguns autores consideravam que ela deveria ser tolerada provisoriamente, pois seria ainda mais trágica sua supressão imediata, por razões humanísticas, jurídicas e econômicas. 
Tal é o caso de José Bonifácio, o Moço, que, em discurso na Câmara Legislativa, em 17.7.1867, afirmou que a escravidão nasceu ilegítima, mas se fixou na estrutura social de tal forma que a abolição imediata não seria adequada. Para ele, a abolição deveria ser antecedida da adaptação das condições de trabalho e da inserção dos libertos na sociedade:

Da história de todos os países, a conclusão é esta: não há emancipação sem tempo e sem preparação. É preciso substituir trabalho a trabalho. Isto é um ponto vencido.

Pois bem, como é que nobres ministros substituem ou preparam os braços que se libertarão? Não se sabe. Não se trata de colonização, não se diz uma palavra a respeito de semelhantes pontos! Mas a emancipação é artigo de bandeira! [...] Eu, Sr. Presidente, também sou emancipador, mas emancipador sem esquecer os grandes e vastos interesses do país. Não quero que a emancipação, em vez de benefício, seja uma desgraça para todos. ${ }^{81}$

Comissão Especial nomeada pela Câmara dos Deputados, ao apresentar parecer, em 24.5.1870, também condenou a imoralidade da escravidão, mas a mitigou com considerações sobre a economia nacional e a propriedade senhorial:

Se, para honra do Império do Brasil, não há nenhum brasileiro que não deseje ver extinta a escravidão, não é menos certo que a emancipação entre nós importa uma profunda transformação da vida social, e entende não só com direitos preexistentes à constituição do Estado, respeitados e garantidos por ela, mas ainda com interesses essenciais da ordem pública. (...)

A reflexão e a prudência repelirão possibilidade de qualquer precipitação [...]. Por outro lado, a incerteza produzida pela propaganda de ideias exageradas causa maior dano nos legítimos interesses do país do que a decretação de qualquer medida prudentemente resolvida. É por isso que esta augusta câmara julgou urgente iniciar uma direção previdente, de modo que, respeitada a propriedade atual, e sem abalo da nossa primeira indústria - a agricultura, sejam atendidos os altos interesses que se ligam a este assunto.

A comissão se ufana, reconhecendo que a ideia civilizadora e humanitária da emancipação não encontra adversários no Brasil. $^{82}$ 
O voto em separado do deputado Rodrigo da Silva, membro da referida Comissão, expressa ainda mais didaticamente essa questão:

Disse que não bastava o sentimento cristão e o princípio da igualdade perante Deus, realizado no direito social da igualdade perante a lei, para determinar desde já a solução de tão grave quanto complexo problema.

Que a questão da emancipação dos cativos não era simplesmente uma questão de religião (...); que era a um tempo uma questão social, política, econômica e industrial; que interessava a toda a ordem de relações jurídicas e sociais, e abalava profundamente a potência social produtiva, a riqueza pública, a propriedade agrícola e o crédito do Estado. ${ }^{83}$

O parecer da comissão designada pela Câmara dos Deputados para estudar o projeto que viria a se converter na Lei Rio Branco, em 1871, reconhece como razões para a abolição "a moral cristã", "os preceitos fundamentais da moral social" e " a liberdade do homem" ${ }^{84}$ Contudo, aponta para a necessidade de se levar em conta a propriedade dos escravocratas para a abolição, por se tratar de garantia que é também reconhecida pela lei:

Sim, reconheçamo-lo bem alto: têm eles [os senhores de escravos] interesses reais, extensos, respeitáveis: se da natureza os não receberam como direitos, conferiu-lhes a sociedade, que faltaria a outro dever sagrado, se os esbulhasse do que a lei considerou, bem ou mal, propriedade circunscrita, mas propriedade.

Representa o escravo para o senhor: (...) um capital valioso (...). O capital, como significação de propriedade, não pode ser arrebatado sem indenização, mas pode, como toda ela, ser expropriado por causa de interesse público. [...]

Razão há para reivindicar para o servo a natural liberdade, mas, em virtude da nossa organização, cumpre acompanhar essa reivindicação da indenização do justo preço do seu serviço; ou (se tal preço não pode ser pago) continuar esse serviço com suavidade. ${ }^{85}$

Embora se considerasse majoritariamente que os escravos tinham direito à liberdade, que lhes havia sido tolhida ilegitimamente, tal argumento não foi invocado para libertar os escravos de imediato. Até mesmo em José Bonifácio, 
os argumentos sobre a liberdade são associados à ideia de civilização. De nada valeria libertar sem preparar para a sociedade. Assim, na Representação de 1823, consta que: "para emancipar escravos sem prejuízo da sociedade, cumpre fazê-los primeiramente dignos da liberdade". ${ }^{86}$ Também exemplificam essa concepção argumentos constantes no parecer da comissão especial designada para avaliar o projeto de 1871:

A liberdade é direito do homem, natural, congênito, inauferível. A escravidão coloca uma vasta porção de homens numa classe de vencidos, de párias, de vítimas. Nasceu de um abuso de força, e esta depravada origem pode sim explicar fatos, não consagrar direitos, e muito menos eternizá-los. [... Contudo,] seria isso [a abolição imediata] uma calamidade para a segurança do Estado, para a fazenda pública, para os particulares, e para os escravos. [...] Lançaríamos instantaneamente e, em massa, no seio dela [da sociedade], um elemento que a não conhece, e que também para ela seria desconhecido. Envernizaríamos de liberdade turbas e turbas, não educadas nela, e incapazes de exercer as graves funções do cidadão. ${ }^{87}$

As tensões referentes à propriedade e à liberdade começaram a ser equacionadas na década de 1880 com um só argumento, cada vez mais ventilado no parlamento e de rápido avanço: o título de propriedade dos senhores seria inválido em razão da Lei Feijó, pois, dada a grande taxa de mortalidade dos cativos e a pouca confiabilidade dos registros públicos, a quase totalidade dos escravos então vivos teria adentrado o Brasil posteriormente à entrada em vigor da lei. Inexistindo título de propriedade, seria ilegal o cativeiro, e os supostos escravos seriam homens livres, ilicitamente mantidos apresados.

A importância desse argumento é preludiada na segunda metade da década de 1870, quando a pressão de movimentos civis se faz sentir diretamente no parlamento. A Sociedade Abolicionista Baiana, em 1876, apresentou manifesto que foi lido na tribuna. Nele consta que "é uma iniquidade e uma ilegalidade, um atropelo do direito e um desprezo pelo país, que existam como

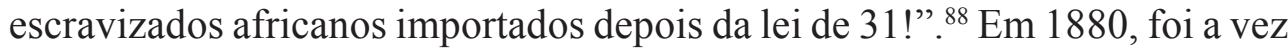
da Sociedade Brasileira contra a Escravidão, que afirmou: "lembrem-se de que é falso que a imensa escravatura do país seja toda possuída legalmente; a matrícula, mesmo, feita com visível má-fé, denunciaria por si só a violação da lei de 7 de novembro de 1831" ${ }^{89}$ Em 1883, a Confederação Abolicionista do Rio de Janeiro assim se manifestou no parlamento: "quer isto dizer que os possuidores de escravos, criminosos de violação da lei de 1831, que não thes admitiu boa-fé, não consentem no país nenhuma vontade que não seja a sua" ${ }^{90}$ 
Ainda em 1883, o senador Silveira da Motta apresentou requerimento para a obtenção de estatísticas oficiais que pudessem identificar quantos africanos teriam sido introduzidos no país na vigência da lei de 1831, que foi negado. Em 1884, no parecer de Ruy Barbosa sobre projeto que viria se converter na Lei Saraiva-Cotegipe, a questão da aquisição ilegal, por força da lei de 1831, é novamente invocada. ${ }^{91}$ Joaquim Nabuco, em discurso de 3.7.1885, também sustentou que, antes de se tentar aprovar novas leis, melhor seria cumprir a lei de $1831 .^{92}$ José Bonifácio, o Moço, em 8.10.1886, afirmou que:

Arrede o nobre Ministro para longe de si todas as reflexões religiosas, todos os preceitos jurídicos; sufoque os instintos da caridade e sepulte a Lei de 1831; ainda assim o estado do País há de convencê-lo que é necessário acabar quanto antes com a escravidão, lepra que nos corrói e vulcão que nos ameaça. ${ }^{93}$

Nas discussões sobre o fundo de emancipação criado pela Lei SaraivaCotegipe, a exasperação da disputa é evidente - ocorre uma verdadeira partidarização do argumento moral. A Lei Feijó, que tivera tão poucos efeitos práticos, tinha agora enorme peso retórico.

De um lado, estavam aqueles que criticavam as indenizações em razão da ilegalidade da propriedade escrava em geral após a Lei de 1831. Do outro, vários parlamentares discutiam valores das alforrias, ignorando discussões sobre o título de propriedade. Dois discursos são especialmente ilustrativos. Enquanto o senador Jaguaribe e o senador Paranaguá afirmavam que aceitariam honradamente os míseros valores pagos pelo governo, dando a entender que desfalcariam sua propriedade para facilitar a abolição ${ }^{94}$; José Bonifácio, o Moço, zombava do parlamento, que, silenciando "sobre a existência ou não existência da Lei de 1831", apressou-se "a legitimar de certo modo a avaliação de Piracicaba [referente às indenizações devidas pelas alforrias]". ${ }^{95}$

A Lei Saraiva-Cotegipe foi vista como uma bravata da bancada ligada aos senhores de escravos.

Em primeiro lugar, o governo insistia que a lei traria em treze anos o fim de toda a escravidão no país, o que era inviável, a não ser por uma superestimação proposital do número de alforrias voluntárias, o que punha de manifesto a falta de compromisso de parte do parlamento. Nas palavras do senador José Bonifácio, o Moço: "todos os atos do Ministério da Agricultura parecem dominados pelo pensamento superior de prolongar a instituição maldita". ${ }^{96}$

Outra razão foi a que gerou maior indignação, relacionada com a cobiça dos senhores de escravos. A Lei Rio Branco somente estipulara a indenização para aqueles senhores que abrissem mão do trabalho dos recém-nascidos até os 21 anos, no valor de 600 mil réis. A Lei Saraiva-Cotegipe, por sua vez, definiu 
indenizações de até 900 mil réis para escravos, cobrindo todas as idades e criando um fundo público para custear as alforrias.

Com a Lei Saraiva-Cotegipe, os senhores expandiam o universo e o montante de suas indenizações em relação à Lei Rio Branco. Tratava-se de tentativa, de, a posteriori, encarecer as alforrias. Isso trouxe imensa indignação para os defensores da validade da Lei Feijó: como ousariam os "falsos proprietários" em tentar aumentar seus ganhos? Não satisfeitos em lucrarem à sorrelfa da lei, ainda quereriam proteger os lucros devidos por má-fé, contrários ao interesse nacional? O senador Joaquim Nabuco critica duramente o projeto, que "tarifa a mercadoria humana acima do seu preço corrente" e "empenha os recursos do Estado por um prazo (...) que tem de funcionar talvez no vácuo do Tesouro Nacional" ${ }^{97}$ Tratar-se-ia, então, de "um verdadeiro retrocesso da moral pública", ${ }^{98}$ em relação à Lei Rio Branco.

É o irônico comentário do senador Araújo Lima:

Para a solução de tais dúvidas não seria de bem avisada prudência abraçar, na libertação dos sexagenários, uma transação compensadora, que, quando hoje caiba, desafronte a humanidade e a dignidade nacional dos escândalos vitoriosos do tráfico africano, ante a lei e a fé solene dos tratados?

Ou preferirão os inimigos do abolicionismo a legalidade estrita? ${ }^{99}$

Os significativos embates nas discussões da Lei Saraiva-Cotegipe levaram à polarização do debate entre aqueles que defendiam as indenizações e aqueles que afirmavam que os "falsos proprietários" queriam se enriquecer com verbas públicas. As discussões da Lei Áurea demonstram a vitória do segundo grupo. Em 1888, são poucas as vozes contrárias à abolição imediata e a favor das indenizações.

\section{Associando ideias e leis}

A abolição da escravatura contou, desde a independência, com o respaldo da condenação moral da escravidão nos debates legislativos no parlamento brasileiro. Tem-se noção de que a escravidão é contrária à moral e que, dessa forma, deve ser expurgada. Contudo, o discurso abolicionista prevalente foi majoritariamente realista - a abolição interessava do ponto de vista moral, mas trazia um significativo ônus social e econômico imediato, por se tratar de instituição fortemente arraigada no país.

Em um primeiro momento, em que as discussões enfatizavam a proibição do tráfico, predominaram argumentos referentes à segurança pública. As pressões inglesas foram ao mesmo tempo construtivas e destrutivas. A Lei 
Feijó não surtiu grandes efeitos à época, somente sendo resolvida a questão do tráfico com a Lei Eusébio de Queiroz.

Após a proibição do tráfico, na década de 1850, propostas no sentido da abolição gradual multiplicaram-se. Os argumentos para a abolição imediata eram considerados radicais, pois trariam significativos riscos econômicos e de segurança pública.

Nesse segundo momento, que se estendeu até antes da década de 1880, as discussões no Parlamento tiveram maior efervescência. Os argumentos políticos foram acompanhados por argumentos morais e econômicos. Começou-se a vislumbrar que a abolição gradual traria, em longo prazo, dividendos sociais, políticos e econômicos.

Se o apoio à abolição gradual era forte, por que ele demorou tanto a concretizar-se? A abundância foi o problema: fosse pela idade ou pela indenização, cada texto defendia ser a melhor maneira de se evitar o caos e a insegurança. O citado parecer de 1871 resumiu essa questão. Caso se fixasse prazo: "Os filantropos, qualquer que o prazo fosse, o achariam longo; os interessados o proclamariam curto". Caso se optasse, ao invés de fixar o prazo, por fazer sucessivas manumissões indenizadas: "o algarismo anual do fundo representaria enorme gravame aos contribuintes". ${ }^{100}$

Após a aprovação da Lei Rio Branco por um gabinete conservador respaldado pelo Imperador, as discussões parlamentares se tornam cada vez mais atentas à política partidária, havendo acusações mútuas quanto à atuação predatória ou leniente do grupo oposto - cada partido queria passar a mensagem de que se preocupava com a abolição, sem apoiar o outro. Nem o gabinete de conciliação de José Antônio Saraiva interrompeu isso, como demonstram discursos da época.

$\mathrm{Na}$ década de 1880, especialmente em função da penetração dos movimentos civis no parlamento, os argumentos econômicos, políticos e morais passam por verdadeira reviravolta. Dados econômicos posteriores à proibição do tráfico e à recente emancipação dos nascidos de ventre escravo reforçavam a ideia de que a abolição seria favorável também em curto prazo. Os contatos com abolicionistas estrangeiros trouxeram experiências favoráveis sobre a abolição em outros países. A propriedade dos senhores foi contestada com recurso à Lei Feijó: o Brasil seria um país de escravos comprados ilegalmente e a inexistência de sistemas fiáveis de matrícula ocultaria essa realidade perversa. Os argumentos referentes ao risco sobre a segurança pública praticamente desapareceram: a abolição gradual, já iniciada pela Lei Rio Branco, teria demonstrado que o problema era superestimado.

Com as novas concepções, estava montado o cenário em que a abolição imediata era aceitável, mas ainda persistiam significativas dúvidas sobre a desejabilidade dessa opção. 
A consolidação da mudança de enfoque dependeu de importante gatilho, que definitivamente consagrou o novo discurso. A abolição imediata somente se tornou a melhor solução depois das discussões da Lei Saraiva-Cotegipe. Esse episódio canalizou as insatisfações de vários dos mais importantes políticos brasileiros abolicionistas: Joaquim Nabuco; Ruy Barbosa; José Bonifácio, o Moço; Sousa Dantas...

Por que os debates parlamentares sobre a Lei Saraiva-Cotegipe despertaram a abolição imediata? Afinal, não era a abolição gradual uma proposta razoável? A resposta é simples: não foi um problema relacionado à aceitação da abolição gradual. Ainda em 1886, afirmava-se, sem grandes oposições, que "a ideia da emancipação é uma ideia aceita pelo país, mas que há de marchar gradativa e progressivamente". ${ }^{101}$

O problema da Lei Saraiva-Cotegipe é que ela foi vista como uma bravata por parte da bancada ligada aos senhores de escravos, por duas razões: (i) o prazo cabal da abolição previsto por seus idealizadores era inviável; e (ii) o mecanismo de indenizações dessa lei era ainda mais favorável que o da Lei Rio Branco, levando ao "sobrepagamento" dos senhores de escravos.

Com a indignação que o projeto da Lei Saraiva-Cotegipe suscitou, deu-se verdadeira polarização do parlamento. A fala do senador João Maurício Wanderley, em 1888, embora em tom apologético, por considerar-se injustiçado, sintetiza a cisão causada pelos debates:

Senhores, tem-se querido tornar odiosos àqueles que pugnaram pela restrita execução da lei de 28 de setembro de 1885. Pretendeu-se dividir os brasileiros em escravocratas e não escravocratas, e aqueles que não examinam de perto as coisas acreditaram que existe no Brasil um partido numeroso, como é o partido conservador, que quer a permanência ou a eternidade da escravidão no Império. ${ }^{102}$

Os vícios da Lei Saraiva-Cotegipe serviram para desacreditar os senhores de escravos e para engatilhar a abolição imediata. Mais do que a superação da abolição gradual, a proposta de abolição imediata consolidava a indignação contra a bravata de 1885. A guerra já estava declarada - e houve diversos desertores na discussão da Lei Áurea, desde seu próprio propositor, Rodrigo da Silva, que, anos antes, criticara as repercussões econômicas e sociais da Lei Rio Branco. Com isso, concretizava-se a profecia feita pela Sociedade Brasileira contra a Escravidão, em 1880 - e os senhores, querendo tudo e mais um pouco, ruíram sua base de sustentação:

Aos senhores de escravos por fim nós dizemos, a lei pode proceder convosco de dois modos: protegendo-vos ou responsabilizando-vos. Podeis escolher. A escravidão, da 
qual sois os últimos representantes no mundo civilizado, pode ser extinta de um dia para outro sem que o Estado vos deva compensação alguma. (...) Depende de vós obter essa compensação a título de equidade, e conseguir que o Estado vos trate como amigos e homens de boa-fé. Se opuserdes, porém, como um partido de guerra e combate, (...) se constituirdes uma barreira insuperável diante de cada medida; então a culpa será somente vossa, quando a lei, depois de tantas tentativas frustradas, tiver de proceder convosco, como Lincoln para os proprietários do Sul da União, que ele quis salvar até a última hora, como um poder beligerante e rival. ${ }^{103}$

\section{Notas}

1. DU BOIS, W. E. B. The Suppression of the African Slave Trade to the United States of America: 1638-1870. Nova Iorque: Harvard Historical Studies, Longmans, Green, \& Co, 1986, p. 194.

2. CHALOUB, S. Visões da Liberdade: uma história das últimas décadas da escravidão na Corte. São Paulo: Companhia das Letras, 1990, pp. 19-20.

3. MIGNOLO, W. D. A colonialidade de cabo a rabo: o hemisfério ocidental no horizonte conceitual da modernidade. In: LANDER, E. (org.). A colonialidade do saber: eurocentrismo e ciências sociais. Buenos Aires: CLACSO, 2005, p. 87.

4. ROCHA, A. P. Abolicionistas Brasileiros e Ingleses: a coligação entre Joaquim Nabuco e a British and Foreign Anti-Slavery Society (1880-1892). São Paulo: Editora UNESP, 2009, pp. 17-18.

5. Idem. p. 17.

6. DAVIS, D. B. O problema da escravidão na cultura ocidental. Rio de Janeiro: Civilização Brasileira, 2001, p. 34.

7. Os debates e as propostas legislativas citadas neste artigo estão copilados em sua grande maioria em interessante obra organizada pela Subsecretaria de Arquivo do Senado Federal, a quem devo grande agradecimento. É esta: Senado Federal. A Abolição no Parlamento: 65 anos de luta, 1823-1888. Brasília: Senado Federal, Subsecretaria de Arquivo, 1988, p. 24. Várias referências a seguir dirão respeito a essa obra.

8. A troca de ratificações ocorreu em 13.3.1827, e a escravidão deveria findar três anos depois, em 13.3.1830.

9. Mas, como veremos ao final, teve importância política na retórica abolicionista especialmente desde 1880 .

10. NABUCO, J. $O$ abolicionismo. São Paulo: Publifolha, 2000, p. 71. (doravante: NABUCO, J. O abolicionismo).

11. Senado Federal. Op. cit. p. 81. 
12. Admitindo-se de três a quatro meses de tolerância para que os senhores pudessem providenciar matrícula originária dos escravos que então existiam.

13. IBGE, Centro de Documentação e Disseminação de Informações. Brasil: 500 anos de povoamento. Rio de Janeiro: IBGE, 2007, p. 223. Disponível em: < http://biblioteca.ibge.gov. br/visualizacao/livros/ liv6687.pdf>.

14. Um dos elementos responsáveis por essa ineficácia foi o tráfico interno no Brasil, redistribuindo os escravos onde eram mais desejados. O combate ao tráfico interprovincial não foi objeto de grandes esforços legislativos nacionais, à exceção de duas propostas: a do deputado João Maurício Wanderley, em 11.8.1954, e a do senador Teixeira Júnior, em 3.5.1877. A verdadeira motivação do deputado Wanderley para propor o fim do tráfico interprovincial é difícil de deduzir: tratava-se de grande proprietário de escravos que se manteve fiel opositor da escravidão. Nos parlamentos locais, houve iniciativas contra o tráfico interprovincial no Nordeste. Vide: DRESCHER, S. Brazilian Abolition in Comparative Perspective. In: SCOTT, R., DRECHER, S., CASTRO, I. M., ANDREWS, G., LEVINE, R. The Abolition of Slavery and the Aftermath of Emancipation in Brazil. Londres: Duke University Press, 1988, p. 26.

15. DAVIS, D. B. Op. cit. pp. 442-443.

16. Senado Federal. Op. cit. p. 308.

17. NABUCO, J. Um estadista do Império: Nabuco de Araújo, sua vida, suas opiniões, sua época. Tomo III. Rio de Janeiro: H. Garnier, 1900, pp. 22-23 (doravante: NABUCO, J. Um estadista do Império. Tomo III).

18. Senado Federal. Op. cit. p. 139.

19. COSTA, E. V. Da Senzala à Colônia. São Paulo: Difusão Europeia do Livro, 1966, p. 383.

20. NABUCO, J. Um estadista do Império. Tomo III. p. 27.

21. Quanto a isso, veja-se notícia publicada por Rui Barbosa no Jornal Radical Paulistano: BARBOSA, R. A Emancipação Progride. Radical Paulistano, São Paulo, 25 de junho de 1869. Disponível em: <http:// objdigital.bn.br/Acervo_Digital/Livros_eletronicos/obras_seletas_vol6.pdf>.

22. Senado Federal. Op. cit. p. 269.

23. O que, na prática, levava ao fim do tráfico interprovincial.

24. Superando, inclusive, a $13^{\mathrm{a}}$ Emenda à Constituição dos Estados Unidos da América, que admitia a imposição da servidão como pena para crimes.

25. Ver SILVA, A. R. C. Construção da Nação e Escravidão no Pensamento de José Bonifácio: 1783-1823. Dissertação (Mestrado em História Social do Trabalho) - Instituto de Filosofia e Ciências Humanas, Universidade Estadual de Campinas, Campinas, 1996, pp. 420-423.

26. Senado Federal. Op. cit. p. 18.

27. Idem, p. 19.

28. COSTA, E. V. Op. cit. p. 13.

29. MALHEIRO, A. M. P. A Escravidão no Brasil: Ensaio Histórico-Jurídico-Social, parte 1. Rio de Janeiro: Typographia Nacional, 1866, pp. IX e 36.

30. Senado Federal. Op. cit. p. 75.

31. Vide CHALOUB, S. Op. cit. pp. 196-197. 
32. Senado Federal. Op. cit. p. 18.

33. Idem, p. 27.

34. Ibidem, p. 29.

35. Ibidem, p. 347.

36. Ibidem, p. 452.

37. NABUCO, J. O Abolicionismo. p. 81..

38. Idem, p. 142.

39. Senado Federal. Op. cit. p. 20.

40. SILVA, A. R. C. Op. cit. p. 250.

41. Senado Federal. Op. cit. p. 1072.

42. Ver o Cap. I do Livro XV. MONTESQUIEU, C. de S. De l'esprit des lois. Paris: Garnier, 1784, pp. 61-62.

43. SILVA, A. R. C. Op. cit. pp. 248-249.

44. DAVIS, D. B. Op. cit. p. 473.

45. Idem. p. 477.

46. Senado Federal. Op. cit. pp. 20-21.

47. Idem. p. 81.

48. Ibidem. p. 147.

49. DAVIS, D. B. Op. cit. pp. 472-473.

50. Idem. p. 474.

51. SMITH, A. An inquiry into the nature and causes of the wealth of nations. Edimburgo: Thomas Nelson \& Peter Brown Eds., 1834, pp. 158-159.

52. Senado Federal. Op. Cit. pp. 441-443.

53. José Bonifácio defende a industrialização na representação de 1823 e seu sobrinho, José Bonifácio, o Moço, no discurso de 1867. Idem. pp. 21-22 e 307-308.

54. Ibidem. p. 1042.

55. Ibidem. p. 145.

56. Ibidem. p. 81.

57. Ibidem. p. 21.

58. Ibidem. p. 347.

59. Ibidem. p. 245.

60. Ibidem. pp. 401-402.

61. Ibidem. p. 445.

62. Ibidem. p. 447.

63. Ibidem. pp. 680-687.

64. Ibidem. p. 924. 
65. Ibidem. p. 439.

66. Ibidem. p. 1067.

67. BLACKBURN, R. A queda do Escravismo Colonial: 1776-1848. Rio de Janeiro: Record, 2002, pp. 60-63.

68. O único discurso que encontrei que efetivamente defende a escravidão é aquele do Senador Paulino José Soares de Souza II, já no apagar das luzes, em 13.5.1888. Senado Federal. Op. cit. p. 1081.

69. Idem. pp. 23-24.

70. Ibidem. p. 81 .

71. Ibidem. p. 142.

72. Ibidem. p. 149.

73. GURGEL. A. E. Uma Lei para Inglês Ver: A Trajetória da Lei de 7 de Novembro de 1831. Justiça e História. Porto Alegre, v. 6, n. 12, 2006, p. 4.

74. Senado Federal. Op. cit. pp. 133-134.

75. HOLCOMBE, J. P. Is Slavery Consistent with Natural Law? Southern Literary Messenger 27 (1858), p. 402.

76. Idem. p. 404.

77. Ibidem. p. 410.

78. Ibidem. p. 412. (Livre tradução).

79. A obra em questão, embora não referida, é Chartism, de 1840: CARLYLE, T. Chartism. Boston: Charles C. Little and James Brown, 1840.

80. HOLCOMBE, J. P. Op. cit. p. 418. (Livre tradução).

81. Senado Federal. Op. cit. pp. 309-310.

82. Idem. pp. 342-343.

83. Ibidem. pp. 389-390.

84. Ibidem. p. 440-441.

85. Ibidem. p. 444.

86. Ibidem. p. 24.

87. Ibidem. pp. 443 e $448-449$.

88. Ibidem. p. 558.

89. Ibidem. p. 588.

90. Ibidem. p. 639.

91. Ibidem. pp. 736-737.

92. Ibidem. p. 818.

93. Ibidem. p. 1021.

94. Ibidem. p. 621.

95. Ibidem. p. 1022. 
96. Ibidem. p. 990.

97. Ibidem. pp. 818-819.

98. Ibidem. p. 822.

99. Ibidem. p. 737.

100. Ibidem. p. 452.

101. Ibidem. p. 1018.

102. Ibidem. p. 1064.

103. Ibidem. p. 588.

Recebido em 10/09/2016

Aprovado em 04/02/2018 